\title{
El cuerpo abortado: retórica fotográfica en la película Roma.
}

\author{
The aborted body: photographic rethorics on Roma.
}

DOI: $10.32870 /$ sincronia.axxv.n80.28b21

\author{
César Antonio Camacho Gámez \\ Maestría en Literaturas Interamericanas. Universidad de Guadalajara. (MÉXICO) \\ CE: ccgamez@live.com / ID ORCID: 0000-0002-4436-2404
}

Esta obra está bajo una Licencia Creative Commons Atribución-NoComercial 4.0 Internacional

Recibido: $31 / 03 / 2021$

Revisado: $16 / 04 / 2021$

Aprobado: 23/05/2021

\section{RESUMEN:}

En este trabajo se analiza Roma, del director Humberto Cuarón, a través de una retórica de la imagen según Roland Barthes. Es un estudio sobre la connotación de un cuerpo fílmico en la construcción de sentido. Aborda la semiótica de la fotografía en la transmisión de mensajes cinematográficos aplicada a la escena del Halconazo para interpretar el significado de la referencia a la masacre de Corpus Christi.

Palabras clave: Retórica fotográfica. Semiótica. Connotación. Denotación. Cuerpo

\section{ABSTRACT:}

This work analyzes Rome, by the director Humberto Cuarón, is analyzed through an image rhetoric according to Roland Barthes. It is a study about the connotation of a filmic body in the construction of sense. It approaches photography semiotics to the transmission of 
cinematographic messages applied to the Halconazo scene in order to interpret the meaning of the reference of the Corpus Christi massacre.

Keywords: Photographic rethorics. Semiotics. Connotation. Dennotation. Body

"Amor es... recordar tu primer beso" Camisa de Fermín en la película Roma.

\section{Introducción}

Roma fue una notoria producción de 2018. Entre centenas de premios no faltaron las críticas. Pero fue una enunciación cinematográfica que resonó fuerte y claro. Este mensaje es un acto comunicativo que se puede estudiar a través de una retórica de la imagen. Porque el lenguaje cinematográfico de Cuarón tiene elementos que explican la teoría fotográfica de Barthes. En Un mensaje sin código, critica el imperio lingüístico sobre el territorio semiótico. Esto es, que la imagen es tan parte de la significación como el signo. Él demuestra esto a través de procesos connotativos en meras fotografías de publicidad cargadas con significaciones culturales, ideológicas, sociales, políticas, etcétera. Claramente esto también ocurre en una propuesta fílmica. Por lo que se propone la hipótesis de que la escena del Halconazo connota el aborto de un cuerpo social.

¿Cómo se formula la postura crítica de Cuarón frente a la masacre de 1971 por medio de la retórica fotográfica? ¿Cómo una película enuncia una posición más allá del diálogo de sus personajes? ¿Cómo se codifica un hecho histórico por medio de la ficción cinematográfica? El éxito de la película Roma puso en debate aspectos sobre la identidad y la violencia en México. En una cápsula de la U.N.A.M. al respecto de la escena del Halconazo se le reconoce a la película "la capacidad del cine como catalizador de la memoria colectiva y medio de difusión de la historia" (Ricardo, min. 3:31 - 3:37). Esto no ha sido ajeno a la crítica de la obra, pues ha sido bien señalado. Pero más que presentar un acontecimiento, la ficción está sujeta al juicio de cómo se representa. Por lo tanto, no se trata de alabar la capacidad de adaptación de Cuarón. Sus premios ya le han 
valido. Pero surge el cuestionamiento de la reconstrucción estética del recuerdo ya no como testimonio sino como sanción de un fenómeno histórico. Porque el director no significa esa postura con los signos verbales o diálogos de los personajes sino con la retórica fotográfica de la escena.

La connotación de una retórica de la imagen se puede enmarcar en las teorías descritas por Roland Barthes. Un mensaje sin código es una colección de ensayos sobre semiótica y fotografía. Fueron publicados originalmente entre 1961 y 1982 en la revista Communications. Ahí describe su tesis sobre la connotación y la denotación en la imagen. El autor propone que el

[...] carácter puramente denotativo de la fotografía, la perfección y la plenitud de su analogía y, en resumidas cuentas, su objetividad, corren el riesgo de ser algo mítico (son rasgos que el sentido común le atribuye a la fotografía): pues de hecho, hay una gran probabilidad (y ésta será una hipótesis de trabajo) de que el mensaje fotográfico (al menos, el mensaje de prensa) también sea connotado (2017, p. 11).

La retórica de la imagen de Barthes no es lingüística, pero sí usa sus recursos para explorar procesos semióticos más allá del signo lingüístico. Por eso aplica los conceptos de denotación y connotación al discurso visual. Es cierto que sus análisis se centran en la fotografía de prensa. Pero ofrecen una metodología semiótica para la connotación cinematográfica de un mensaje que alcanzó una gran cantidad de receptores. Es interesante porque la denotación del embarazo interrumpido de Cleo en Roma, connota la significación con que se referencia el Halconazo.

\section{El objeto de estudio: Roma}

La película Roma (Cuarón 2018a) es un retrato urbano. Es memento de una colonia en la ciudad de México. Entre todos los tránsitos resalta la continuidad entre infancia y maternidad. Aunque Roma es autobiográfica, la presencia de Cleo inaugura la película. La prensa presentó la narración como "la historia de Cleo, una empleada doméstica que mantiene a flote a una familia de clase media en el convulso Distrito Federal de los inicios del gobierno de Luis Echeverría" (Lima, 2019). Esto quiere decir que su cuerpo establece un aquí y un ahora en la memoria. La interrupción de su embarazo 
como conflicto une el planteamiento de un ama de casa de la colonia Roma en el México de la masacre de Corpus Christii en el 71. El planteamiento de la película se denota en el fotograma de las lavanderas en las azotas, las condiciones de una clase social. El nudo es el de un embarazo que se interrumpe. Y el clímax es la toma de consciencia que Cleo hace en el mar de la escena final.

Roma es un constante juego de espejos. Su inicio es un reflejo al infinito, mientras que Sofía y Cleo son una refacción de la maternidad en dos clases sociales. Así como el mar le brinda a Cleo la imagen de sí misma que le permite asumir que ella no quería el embarazo. La película fue bien recibida. Se ha dicho que

[...] la cinta ha sido galardonada por un sinnúmero de premios internacionales, y las reseñas han resaltado el excelente balance entre el film semi-autobiográfico y el drama familiar, sin olvidar la crítica social y política del México setentero que Roma denuncia, una denuncia tan sutil como devastadora. (Esterrich, 2019, p. 212).

Esta postura que ha premiado a la cinta se basa en el impacto cultural de la memoria social. No es sólo el Halconazo, pues hay más reflejos de lo político en la sociedad, o las condiciones de género o clase que oprimen a Cleo, la ausencia paternal en modelo fracasando, todo permea la narrativa fílmica. Pero en esa escena de la masacre estos sesgos se manifiestan fotográficamente. Por lo tanto el sentido impreso en el relato es más expreso. $Y$ esta es una manera en que se puede estudiar la denotación y connotación en fotografía.

La película se centra en México pero ha superado fronteras. En primera porque el director tuvo que cruzarlas de regreso para grabarla. Pero hay contradicciones interesantes en una ciudad llena de movimiento, inmóvil en su espacio, que transita como imagen a través del mundo. Por lo tanto no es de extrañar que la película también alcanzó la crítica extranjera. Contrario a la perspectiva de Esterrich se ha dicho que "esa inercia extraña de la cámara, su rechazo a comprometerse con el drama, se traduce como la manera palpable en que Cleo se desenlaza del patético rol de la sierva obediente lista para el sacrificio" (Žižek, 2019). Eso quiere decir que la idea de familia opone dos lecturas muy distintas de la película. ¿Hay un tributo al trabajo doméstico que 
salva familias o una crítica la trampa capitalista que le hace salvar a la familia del opresor y condenar a la propia? Las teorías de Roland Barthes no sólo sirven para matar al autor, también para acceder a sus posturas críticas; porque una cosa es la dificultad de una colectividad artística para denotar la historia e incidir en la memoria del espectador, y otra la connotación fotográfica, que de acuerdo con Barthes, profundiza en la postura crítica tras todo el trabajo cinematográfico.

\section{Barthes y la retórica de la imagen}

Desde el Crátilo de Platón está presente la discusión sobre la cualidad analógica del lenguaje. La relación de las palabras con los objetos que designan, tienen una dicotomía en español cuyos orígenes datan de la lengua latina. La denotatio y la connotatio se relacionan etimológicamente con la oposición denotación y connotación. Denotar y connotar se oponen en el acto de notación o de nominación, la manera en que se asignan nombres al mundo. Beristáin define connotación de la siguiente manera: "Propiedad que poseen los signos de agregar un segundo (o tercero, etc...) significado al significado denotativo que es inmediatamente referencial: el de las palabras en los diccionarios" (1984, p. 110). Una semiótica como la lingüística estudia ese significado denotativo como la relación estable entre un objeto y el signo que una lengua le atribuye. Tal estabilidad no es del todo fija. Al cambiar la lengua cambia el signo, y esto incluso ocurre desde variaciones dialectales, sociolectales o idiolectales - de ahí la famosa arbitrariedad del signo según Saussure o que las palabras no son analógicas como quería Platón. De cualquier manera la denotación ocurre cuando más de dos personas llaman algo de la misma forma. La fotografía se brinca las palabras y pone la forma del objeto como signo. Por eso Barthes parte del principio de que la fotografía es denotación pura (2017, p. 9); en lugar de hablar de algo, lo muestra. Pero cuestiona que los mensajes fotográficos poseen más niveles que el de la relación analógica de la realidad, y es allí donde ocurren los procesos de connotación fotográfica.

El arte como analogía de la realidad genera las tensiones entre ficción y no ficción. Que la vida no son cuentos o películas es la postura de quien exige acciones y no palabras. Un niño vive esto cuando se le habla de un dulce y luego llora porque no tiene ese dulce en la mano. Pero la 
frase latina de acta est fabula (actuar es fabular) ya implica que la distancia entre el arte y la realidad no es tan sencilla como ir de A a B. Hjelmslev (1984) señala que "hay también semióticas cuyo plano de expresión es una semiótica y semióticas cuyo plano del contenido es una semiótica. A las primeras las llamaremos semióticas connotativas; a las segundas, metasemióticas" (1984, 160). Entonces la connotación ocurre cuando el significado denotativo se desdobla hacia más significados. Las artes se especializan en esto. Si en una pintura o fotografía los significantes, las imágenes, o en literatura, las palabras, están arregladas para modificar el sentido denotativo de lo expresado se habla de las semióticas connotativas mencionadas. Las metasemióticas derivan sentidos generados a partir de esa connotación. Esto ocurre cuando tales significados se hayan en oposición o en tensión con estructuras culturales, sociales o ideológicas por ejemplo.

La clasificación hjelmsleviana de semióticas denotativas, connotativas y metasemióticas sirve para contrastar las tensiones entre denotación y connotación que hace Roland Barthes. Él analiza el mensaje fotográfico con funciones lingüísticas para hablar de una retórica de la imagen. Un mensaje sin código centra su análisis en la fotografía de prensa. Pareciera que, a diferencia de otras reproducciones analógicas de la realidad, el periodismo no desarrolla un mensaje suplementario al contenido por analogía. Barthes dice que "dibujos, pintura, cine, teatro [...] implican dos mensajes: un mensaje denotado, que es el analogón en sí, y un mensaje connotado que es cómo la sociedad, en cierta medida, da a leer lo que piensa al respecto" $(2017$, p. 9). Si la fotografía es el analogón perfecto, la dirección fotográfica de una película usa ese recurso. Es más fácil creer en una imagen que en una palabra porque es (e)vidente. Pero eso es pura retórica. Es por eso que Barthes estudia los procesos de connotación de la imagen. De acuerdo con esta teoría en la fotografía los objetos dejan de ser una superficie de inscripción para la significación y se vuelven signos cargados con significados dados por su relación con los otros objetos en el cuadro. Tanto en la prensa como en el cine se limita la relación infinita de significados que puede tener un objeto con un número finito, aunque no necesariamente escaso, de relaciones.

En Un mensaje sin código la discusión sobre la connotación de la fotografía de prensa no se centra en otras artes imitativas. Sin embargo a lo largo del texto hay varios ejemplos con pinturas, 
dibujos o películas. Además esto se debe a que los procedimientos de connotación no son tan obvios en las imágenes periodísticas. Pero la metodología desarrollada por Barthes puede orientar hacia un análisis connotativo sobre la fotografía cinematográfica. Él señala que

La connotación, es decir, la imposición de un sentido secundario al mensaje fotográfico [...] es, en suma, una codificación del análogo fotográfico; por ende, es posible ir desentrañando procedimientos de connotación; [...] habría que separar bien los tres primeros (trucaje, pose, objetos) de los tres últimos (fotogenia, esteticismo, sintaxis) (2017, p. 12).

La aplicación metodológica y definición teórica de estos procedimientos ocupará la siguiente parte del trabajo. Estos seis procedimientos de análisis ofrecen resultados para estructurar los tres diferentes niveles en que opera la connotación. Ya se ha señalado que Hjelmslev llama a estos niveles semiótica, semiótica connotativa y metasemiótica. En relación al mensaje fotográfico Barthes los define como connotación perceptiva, connotación cognitiva y connotación éticaideológica, que se corresponden con un mensaje lingüístico o literal, luego como un mensaje icónico codificado y por último como un mensaje icónico no codificado. La correspondencia de estos términos es respectiva a los tres niveles connotativos que se interpretarán de acuerdo a los resultados al análisis de los seis procedimientos de connotación.

\section{Metodología de la connotación}

La lectura denotada de la escena del Halconazo es su pertinencia al relato fílmico. Da cuenta de lo que ocurre al embarazo de Cleo. En este sentido su connotación es la de la angustia en el espectador por medio de la prefiguración de la pérdida de su hija, que nace muerta. Estos son los dos primeros niveles de significación, el del mensaje lingüístico (Barthes) o semiótico (Hjelsmlev) y el mensaje connotado codificado (Barthes) o semiótico connotativo (Hjelsmlev). Atienden a la significación de la trama. Aquí el entorno social de represión estudiantil cataliza la pérdida de la hija de Cleo. Y entonces en el mensaje connotado no codificado (Barthes) o metasemiótico (Hjelsmev) los significados se desdoblan para que entonces la experiencia de Cleo tenga lugar en la 
construcción de sentido en torno al Halconazo. Para determinar este movimiento de la significación hay que atender a la siguiente Tabla de los procedimientos de connotación. A continuación se analizan el trucaje, la pose, los objetos, la fotogenia, el esteticismo y la sintaxis en la fotografía de la escena.

\begin{tabular}{|c|c|c|c|}
\hline & $\begin{array}{c}\text { Argumento de } \\
\text { Barthes }\end{array}$ & $\begin{array}{c}\text { Argumento } \\
\text { teórico }\end{array}$ & Argumento fotográfico \\
\hline Trucaje & $\begin{array}{l}\text { "El interés } \\
\text { metódico del } \\
\text { trucaje consiste en } \\
\text { que este } \\
\text { interviene en el } \\
\text { interior mismo del } \\
\text { plano sin } \\
\text { denotación, la } \\
\text { aviso; utiliza la } \\
\text { credibilidad } \\
\text { particular de la } \\
\text { fotografía, que se } \\
\text { limita, como } \\
\text { hemos visto, a su } \\
\text { excepcional poder } \\
\text { de denotación, } \\
\text { para hacer pasar } \\
\text { por simplemente } \\
\text { denotado un }\end{array}$ & $\begin{array}{l}\text { “¿Cuál es el lugar } \\
\text { del mundo que } \\
\text { prá siendo re- } \\
\text { Incluso si hay una } \\
\text { respuesta, } \\
\text { ciertamente es } \\
\text { radicalmente } \\
\text { diferente a la que } \\
\text { uno ofrecería } \\
\text { normalmente } \\
\text { sobre la cuestión } \\
\text { de aquello que } \\
\text { está siendo } \\
\text { representado por } \\
\text { tal trucaje } \\
\text { fotográfico, } \\
\text { procesos de la } \\
\text { fotomontajes”. }\end{array}$ & $\begin{array}{l}\text { Roma representa con su cámara un } \\
\text { espacio donde se cancela la compra } \\
\text { de una cuna como ritual de consumo } \\
\text { como solución al drama familiar de } \\
\text { la paternidad ausente. Sobre el } \\
\text { consumo en el plano secundario se } \\
\text { pone en primer plano la presencia } \\
\text { militar y los cánticos de protesta. En } \\
\text { la mera discusión sobre el precio a } \\
\text { pagar surge el histórico grito de } \\
\text { ¡Viva el Che Guevara! La pistola en el } \\
\text { primer plano termina esta } \\
\text { comunicación en una síntesis } \\
\text { enfática de violencia. Los travelling } \\
\text { tienen una dirección: del énfasis al } \\
\text { flujo, de la catarsis social a la } \\
\text { catálisis de sentido que emana junto } \\
\text { con la fuente rota de Cleo; algo le } \\
\text { ocurre a la infancia, a la juventud. }\end{array}$ \\
\hline
\end{tabular}




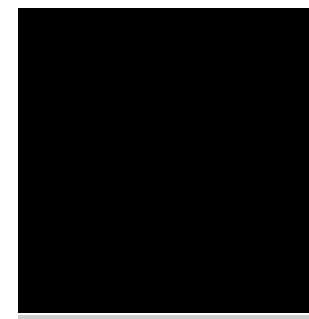

Pose

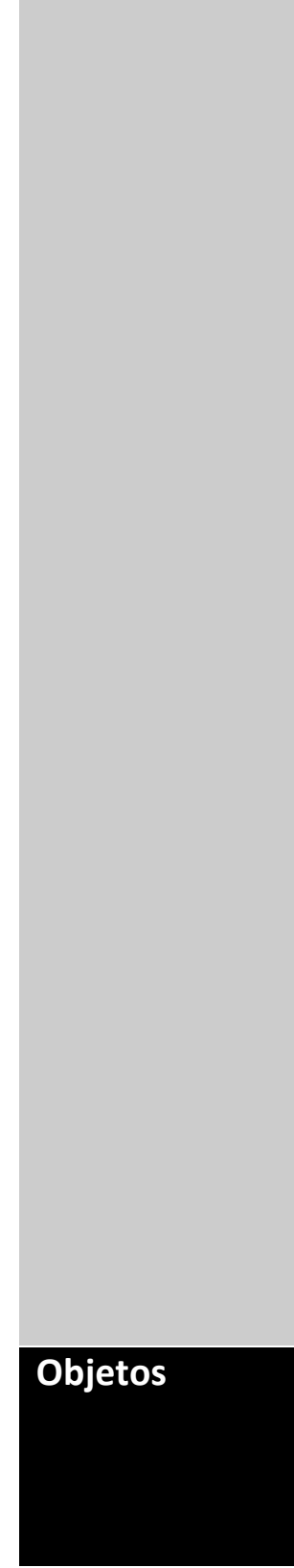

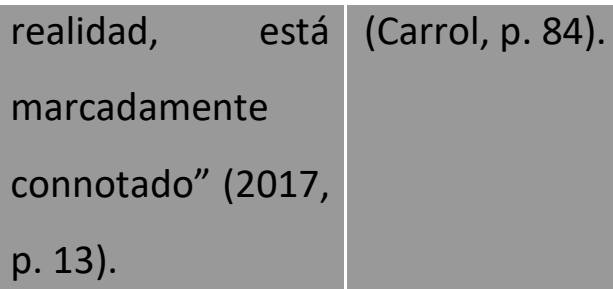

"En este caso, es la pose misma lo instancia que prepara los enunciante en significados de cuanto principio connotación" de (2017, p. 14). resistencia/impuls o material, pero también cuanto posición de referencia, conjunto material que ocupa una porción de la extensión, a partir de la cual se organiza dicha extensión

(Fontanille, 2018, p. 33).

\begin{tabular}{lr|l|lll}
$\begin{array}{lrl}\text { Funcionan como } \\
\text { "inductores }\end{array}$ & "Pero así como el & La disposición de los objetos en la \\
objeto en general & escena del Halconazo no es aleatoria \\
comunes de & no existe más que & sino que están dispuesta al
\end{tabular}




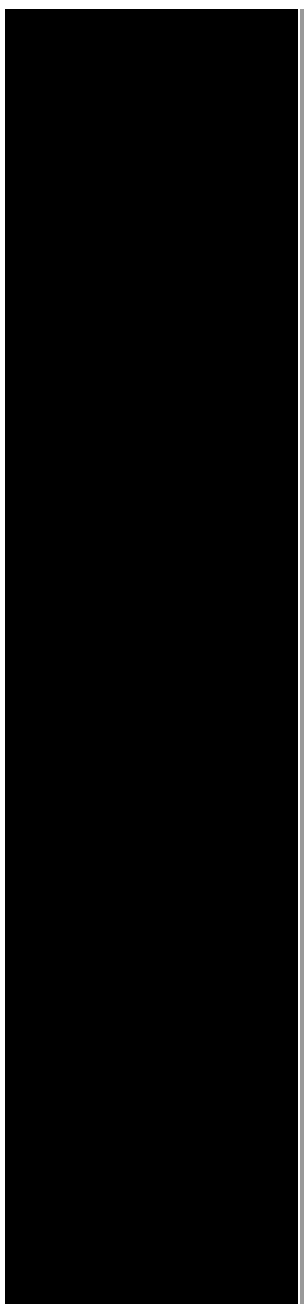

Fotogenia

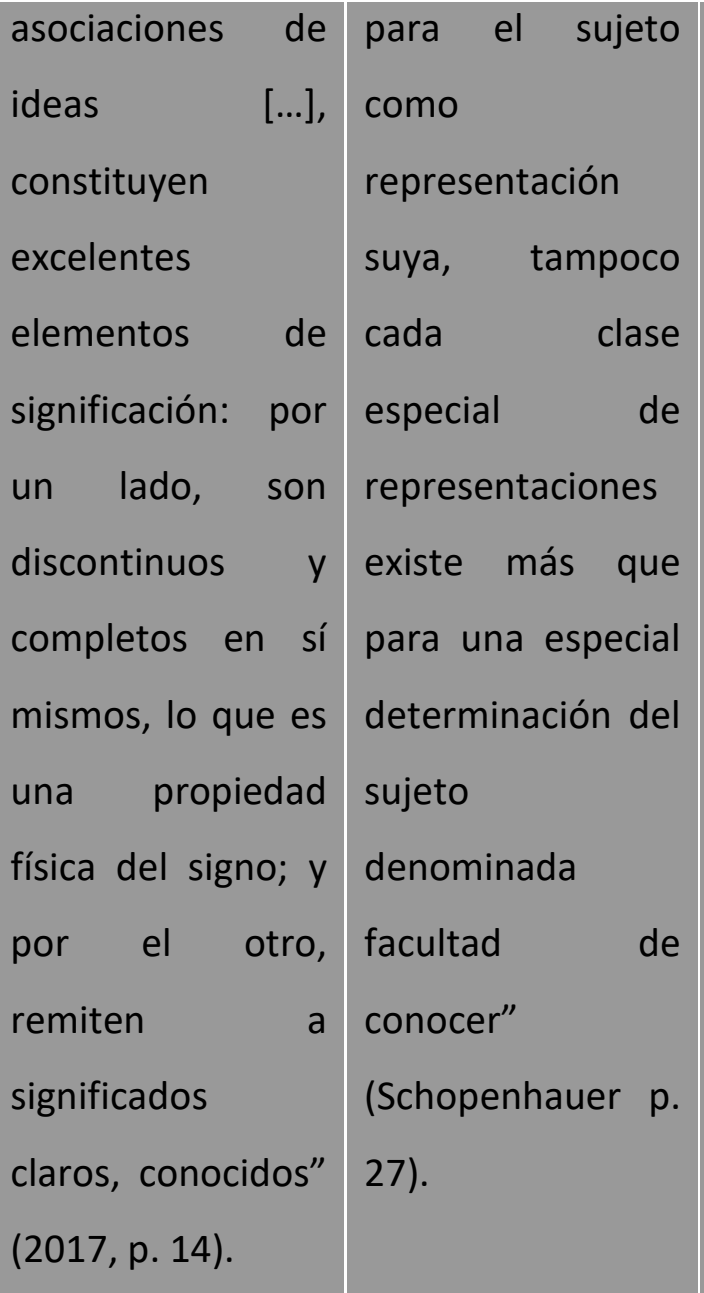

"En la fotogenia,

¿Cómo

definir

el

mensaje

esta cualidad que

connotado está en

no está en la vida,

la imagen misma, sino en la imagen

"embellecida" (es de la vida? La

decir, en general,

sublimada)

mediante técnicas

de iluminación, de señalamiento de la cancelación del sujeto de conocer. Esto se relaciona con la objetivación del cuerpo en cadáver por medio de la violencia y la presencia de zapatos tirados en la calle cuando Cleo y el resto huyen. EI cuerpo vuelto objeto cancela al sujeto y cancela el principio de razón del que habla Schopenhauer, el sujeto del conocer, vuelve los cuerpos parte de la cadena de causalidad.

Una de las principales fotogenias de Roma es la calle vuelta mural. Guillermo del Toro ya había señalado en un twit (2019) esta característica que ocurre con los travelling en la película. Este mural señala la aspecto poético colusión de esas fuerzas públicas con extremo de los las paramilitares. De esta manera un seres y de las muralismo callejero usa los sentidos 
(Louis de crítica de la tradición del esta muralismo revolucionario. Huelga revelado" (2017, Delluc) cualidad poética mencionar además una estrategia de los seres y de refractaria, reflexiva o caleidoscópica las cosas (León de los planos en escena. El cartel Moussinac) haciéndose con carteles al fondo, la susceptibles de cuna comprándose con compradores sernos reveladas al fondo, el carro en el tráfico de exclusivamente fondo la pistola apuntando a Cleo por

el con pistolas matando estudiantes al cinematógrafo fondo. Esa reproducción (Morín, 2001, p. infinitesimal, que se ve también en 23).

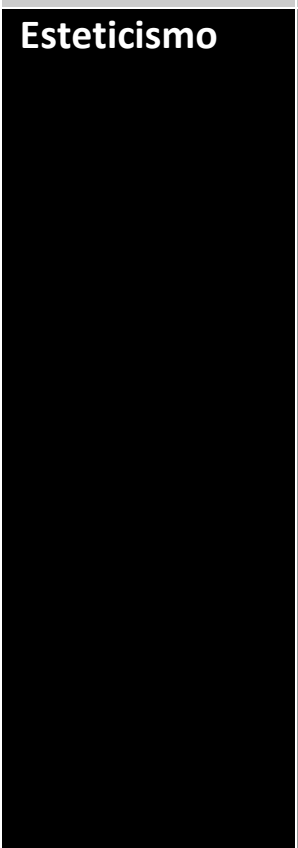

\begin{tabular}{|c|c|c|}
\hline $\begin{array}{l}\text { “Cuando la } \\
\text { fotografía se hace } \\
\text { pintura, es decir, } \\
\text { composición } \\
\text { sustanciosa visual } \\
\text { deliberadamente }\end{array}$ & $\begin{array}{l}\text { En este contexto } \\
\text { se señalan } \\
\text { algunos } \\
\text { fotogramas. El } \\
\text { primero en } \\
\text { 1:32:07 (el carro } \\
\text { yendo hacia una } \\
\text { manifestación de } \\
\text { fondo), el } \\
\text { segundo en } \\
\text { 1:33:38 (la mirada }\end{array}$ & $\begin{array}{l}\text { Son cuadros específicos de } \\
\text { significación que podrían funcionar } \\
\text { por sí mismos. En ellos, el } \\
\text { espectáculo del cine caracteriza los } \\
\text { valores insertos en las imágenes. La } \\
\text { atribución axiológica opera en que la } \\
\text { familia burguesa también es presa de } \\
\text { lo mismo que la marcha critica } \\
\text { (primer fotograma), en que la } \\
\text { presencia de los paramilitares se } \\
\text { objetiva en sus armas (segundo }\end{array}$ \\
\hline
\end{tabular}




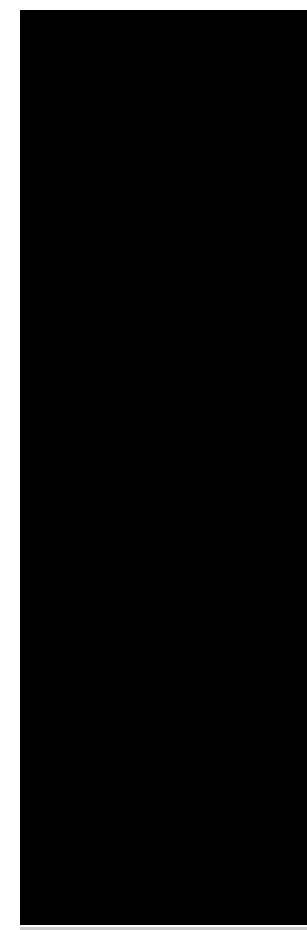

Sintaxis

\begin{tabular}{l|l|l} 
imponer un & del kendo hacia la \\
significado por lo & marcha), el \\
general más sutil y & tercero en 1:35:05 \\
más complejo de & (el empaste de la \\
lo que sería & pistola matando \\
posible con otros & estudiantes \\
procedimientos & apuntando a Cleo) \\
de connotación" & y un cuarto en \\
(2017, pp. 15-6). & $\begin{array}{l}\text { 1:36:38 } \\
\text { estridente de un }\end{array}$ \\
& desesperado grito \\
& de ayuda).
\end{tabular}

“El

significante de connotación

entonces ya

no se

encuentra a

nivel ninguno

de los

fragmentos

de la

secuencia,

sino al nivel

(suprasegmen

tal, dirían los
"La sintaxis es

la parte

fundamental

de la

gramática que

estudia las

relaciones

que se

establecen

entre las

palabras

dentro de una

oración;

también se
La estructura sintáctica de la escena del Halconazo es una espiral de violencia. El enunciado de la escena comienza con el sujeto burgués (familia en el vehículo) interrumpida en su excursión de caridad por una marcha estudiantil, un objeto indirecto condicionado por un objeto circunstancial de carácter marcial, esto es, el himno nacional y el ejército del cuarto cuadro. El juego sintáctico de estos casos gramaticales se convierte en una espiral por medio de los reflejos de 


\begin{tabular}{|c|c|c|}
\hline $\begin{array}{l}\text { lingüistas) del } \\
\text { encadenamie } \\
\text { nto" (2017, p. } \\
\text { 16). }\end{array}$ & $\begin{array}{l}\text { ocupa del } \\
\text { significado a } \\
\text { que dan lugar } \\
\text { esas } \\
\text { combinacione } \\
\text { s" (Munguía, } \\
2016, \text { p. 71). }\end{array}$ & $\begin{array}{l}\text { cámara. La yuxtaposición del } \\
\text { séptimo cuadro, mueblería-calle es } \\
\text { un espejo que cuya integración se } \\
\text { rompe agresivamente con la } \\
\text { conjunción adversativa del octavo } \\
\text { cuadro. A partir de aquí sujetos y } \\
\text { objetos gramaticales se vierten en la } \\
\text { espiral de violencia. Hay un } \\
\text { encabalgamiento de los estudiantes } \\
\text { muertos y el feto amenazado, entre } \\
\text { el parto y el ayúdenme estridente. Al } \\
\text { final del enunciado, el objeto directo } \\
\text { que responde a qué se interrumpe, } \\
\text { es la infancia y la juventud. }\end{array}$ \\
\hline
\end{tabular}

\section{4.- Conclusiones:}

Que no todo lo dicho es todo lo significado, y allí radica la importancia de una retórica de la imagen. El significado tampoco se termina en la relación boca-ojos, porque el cuerpo posee múltiples órganos. Estos no sólo ayudan al funcionamiento corporal sino también a la percepción y producción de la significación. Por lo tanto a través del cuerpo de Cleo se tensionan los procedimientos de connotación en Roma. Porque

[...] según los lugares recíprocos que se ocupen, las enunciaciones varían y ya no forman el mismo objeto científico, sin duda, porque dirigirse a otros cuerpos (lo que es, con propiedad, hablar) siempre implica decidir secretamente qué hacemos con esos cuerpos (acercarnos a ellos, evitarlos): en el habla hay un tacto oculto (Barthes, 2017, p. 363). 
Ese contacto lleva del cuerpo denotado al cuerpo connotado. Porque la película representa el sufrimiento femenino en el proceso de un embarazo interrumpido. Pero el plano de secuencia del Halconazo connota el acto abortivo de un cuerpo social. Ahí los flujos se rompen y la consciencia tardará toda la película en asimilar lo que ocurre, en volver a fluir. Tal inmovilización es una forma de la opresión que Cleo encarna tanto en sus dimensiones íntimas como sociales.

En Roma la denotación del embarazo interrumpido lleva a la connotación de un aborto social. ¿Cómo pasar de un cumulo o conjunto de signos a una continuidad de signos para hablar de la escena como un conjunto significante? Esto es, un recorrido que hable de la significación de la escena por medio de una estructura corporal. Primero hay que aclarar que la escena trasciende lo anecdótico de la diégesis fílmica y hace referencia a la cultura mexicana. Está la resonancia del

[...] libro El laberinto de la soledad: el abandono del padre cruel e irresponsable, el sufrimiento estoico de la esposa, el desamparo de los hijos, son hechos que van más allá de un desajuste social. Remiten al trauma de la Conquista de México y el nacimiento mismo de México como país mestizo, hijo ilegítimo de Hernán Cortés y la Malinche (Krauze, 2018, párr. 1).

Para Cleo esta fórmula la violenta pero no la transforma. A través del trucaje de la fotografía, sus poses, sus objetos, su fotogenia, su esteticismo y su sintaxis están en semiosis activa con la cultura. El encuadre urbano y la fotogenia del blanco y negro ponen en movimiento los procesos de connotación. Así como los objetos como pistolas direccionando el sentido de las posturas. También se generan relaciones de significación entre la sintaxis en espiral y los cuadros esteticistas. La complementariedad de los procedimientos de connotación no presenta las imágenes como una aspiración de belleza. Más bien son bellas por significar en consonancia con la cultura donde se emiten.

En resumen los procedimientos de connotación ofrecen claves para la connotación fotográfica de la escena del Halconazo. El trucaje funciona junto con la fotogenia para crear una 
ilusión de cancelación interior/exterior. La realidad fílmica de pronto es suplantada por una realidad histórica, presente en el espectador que reconoce su pasado colectivo. A través de las ventanas se ve la marcha, al interior de la mueblería se escuchen los cánticos. Porque "en la imagen total constituyen rasgos discontinuos o, mejor dicho, erráticos [...pues] no llenan toda la lexía, su lectura no la agota" (Barthes, 2017, p. 100). El caos de la represión es un un error social, que a su vez produce ruido en la vida de Cleo. Pero la discontinuidad de signos encuentra un entrelazamiento semiótico en la connotación. Así la sintaxis describe la espiral de violencia concéntrica hacia una definición del caos en la vida de Cleo, la muerte de su hija. Y esto queda connotado por los objetos presentes en la escena que se acumulan para apuntar a un objeto líquido, la fuente rota. Es por eso que la pose de Cleo, el embarazo interrumpido, es la emanación connotativa de la escena del Halconazo.

Es cierto que Cleo no aborta de manera voluntaria, pero también es cierto que al final reconoce que tampoco quería que naciera. Entre un triunfo priista que puebla las calles tanto con carteles como con neoliberalismo, entre un amor patriarcal y belicoso y una clase subordinada, Cleo no tiene muchas expectativas. En esta fuerte opresión social hay un espacio de inscripción que es donde lo que le pasa a Cleo interpreta el entorno en que discurre. Por eso la connotación se inscribe en el cuerpo que enlaza maternidad e infancia. Roma es una "amorosa apreciación fílmica de un sujeto marginal [...] que nunca llegamos a saber mucho [...que...] permanece al margen, incluso cuando está en el centro [...]: es casi imposible encontrar a Cleo, porque el abrazo familiar la hace desaparecer" (Esterrich, 2019, p. 216). La imposibilidad de familia en el relato de Cleo es una crítica a la figura nuclear de la burguesía, a sus fracasos. Su denotación de un embarazo interrumpido connota un cuerpo abortado. En el nivel ideológico de la connotación, la madre nación está tan corrupta que no puede dar a luz, no puede dar vida. Es interesante cómo el trabajo actoral de Yalitzia Aparicio une el recuerdo de su director con la experiencia de una mujer. Su presencia argumenta que no todos los abortos son intencionados, que muchos abortos ocurren por carencias, que el proceso psicológico es más largo que el embarazo, y que para no juntar todo eso en una 
palabra llamarle interrupción del embarazo no es un eufemismo inútil sino reflejo infinitesimal de condiciones históricas.

Cleodegaria Gutiérrez es heroína porque gana a la histeria de la ausencia fálica a diferencia de su patrona. Ante el abandono de su pareja Sofía castiga sus hijos, se desquita con la entrada de su casa, y aunque sale adelante, muy bien se puede cuestionar que de no ser por Cleo sus hijos terminarían muertos en el mar. La descendencia de Cleo también está muerta, hasta donde el film lo expresa. Pero el mar revela esto como una toma de decisión y no como un accidente, a diferencia de Sofía, aunque es una decisión de la que Cleo toma consciencia hasta el final de la película. En Roma: otra palabra para amor, se señala que la película "termina como empieza, con su protagonista haciendo su rol principal en el cuidado de la casa: ella limpia" (Harrison, 2019). Este juego de anagramas es interesante para la connotación de la escena del Halconazo. Porque el hecho de que la película empiece y termine con agua y con aviones, con tránsitos, pareciera la perennidad del personaje, que no cambia. Pero eso es lo importante del personaje, la resistencia a la opresión, al flujo social que la orillaba a la posición de Sofía como madre, pero marginal en tanto indígena. Cleo rechaza la ausencia del padre que se pierde al irse de viaje entre una marcha militar para regresar con otra esposa, así como la paternidad de Fermín que queda perdida en una ficción marcial. La ineficacia de la mirada clínica del estado en el proceso abortivo tiene un error que lleva el nombre de la protagonista, cuyo esfuerzo en su humilde trabajo le brinda la condición física para realizar una simple postura de yoga que el entrenamiento paramilitar de los halcones no les otorga en su simulación de masculinidad.

¿Cómo el receptor pasa de la memoria urbana a la memoria social? ¿Cómo transita el mensaje de la colonia Roma al Halconazo, de una familia y su sirviente a las masacres estudiantiles en México? Las críticas negativas a la película coinciden en una acusación burguesa. Se ha atacado a Cuarón por beneficiarse de la marginalización e idealizar personajes oprimidos. Žižek comenta que “¿puede ella realmente ser reducida al objeto de amor definitivo de una familia acomodada de clase media alta, aceptada (casi) como parte de la familia sólo para ser explotada, física y emocionalmente?" (2019). Sin embargo el mismo director es consciente de esos problemas, por eso 
los pone en escena, en discusión. Žižek quiere tomar el puesto del director y le escribe un final distinto a Cleo donde lee a Marx y adquiere consciencia de clase para unirse a las marchas estudiantiles. Es cierto que la relación patrona-sirviente cuestiona que una emancipación femenina sin emancipación de clase seguirá reproduciendo esquemas patriarcales. Pero la toma de consciencia individual de Cleo ya es parte del proceso semiótico de emancipación. Para Žižek, Cleo es un personaje incompleto, pues le falta consciencia de clase y militar por el partido, para Cuarón el sufrimiento de Cleo es completamente militante pues representa su tiempo histórico.

La tragedia denotada en Roma es la pérdida de la maternidad de Cleo. La tragedia connotada es la prevalencia de la ficción militar-nacional en las bandas de guerras pero que el himno nacional entonado por la juventud quede silenciado. El cuerpo embarazado de la empleada doméstica enuncia la denotación de un embarazo interrumpido al nivel semiótico del enunciado fílmico. Esto connota un cuerpo social abortado en la represión estudiantil de Corpus Christi al nivel de una semiótica connotativa. El autor dice en entrevista: "A mí lo que más me interesaba además era ese impacto, ese momento donde ahí va a haber un parto con esa fantasía de la modernidad y el progreso en México, y la violencia siempre se pone de por medio" (Cuarón, 2018b, min. 18:3418:54). Y la connotación ideológica o el nivel metasemiótico del significado revela el mensaje fotográfico de la película: una denuncia sobre la mirada abortiva del estado hacia su juventud y la incidencia en la continuidad maternidad-infancia, pero también el fracaso de la familia burguesa. El mar no sólo revela a Cleo su decisión, también revela a la familia su imagen, existen sin ser un modelo nuclear y el modelo de la madre soltera trabajando como familia sin padre ya era toda una realidad desde el siglo anterior. Esto se hace con el fondo del plano de una boda, porque aunque fracase, ese mismo sueño burgués continúa. La anécdota que cuenta el niño acerca de estudiantes lanzando globos con agua que los mataron señala la continuidad maternidad-infancia desde el inicio de la película. La respuesta al padre que rechaza a su prole es una prole que rechaza al padre. El relato se connota con el cuerpo de Cleo y su embarazo interrumpido; cuando vuelven a casa quedan los libros del padre ausente, o sea, tras el aborto social queda la memoria del movimiento 
estudiantil en las páginas de los sobrevivientes, críticos y memoriosos: el cuerpo textual de esa infancia consciente que fue abortada.

\section{Referencias:}

Barthes, R. (2017). Un mensaje sin código. Ensayos completos en la revista "Communications". Argentina: Ediciones Godot.

Beristáin, H. (1984). Diccionario de retórica y poética. México: Porrúa.

Cuarón, A. (2018a). Roma. México. Espectáculos Fílmicos "El Coyúl."

Cuarón, A. (2018b). Preguntas y respuestas de ROMA con Alfonso Cuarón en CDMX. México. YouTube. Versión electrónica disponible en https://www.youtube.com/watch?v=4sQjKQKT5Lw\&t=1128s último acceso 13/12/2019.

Esterrich, C. (2019). “Maternidades heroicas en 'Roma' de Alfonso Cuarón” en Cuaderno 91. Centro de Estudios en Diseño y Comunicación de la Universidad de Palermo: Argentina. Versión electrónica disponible

en https://fido.palermo.edu/servicios dyc/publicacionesdc/cuadernos/detalle articulo.php?id libro=786\&id_articulo=16340 último acceso 13/12/2019.

Fontanille, J. (2008). Soma y sema; figuras semióticas del cuerpo. Perú (Francia). Fondo Editorial Universidad de Lima.

Harrison, J. H. (2019). "Roma: Another word for Amor" en Reviews. U.S.A. Michigan Publishing, University of Michigan.

Hjelmslev, L. (1984). Prolegómenos a una teoría del lenguaje. España: Gredos.

Krauze, E. (14 de diciembre de 2018) Roma, una historia de amor y cerbidumbre. [Página web personal]. En: Enriqeu Krauze. Historiador y ensayista. https://enriquekrauze.com.mx/romauna-historia-de-amor-y-servidumbre/

Morín, E. (2001). El cine o el hombre imaginario. España: Paidós.

Munguía, I. (2016). Gramática de la lengua española: clases de palabras. México: Gedisa Editorial Universidad Autónoma Metropolitana. 
Toro, G. (2019). Citado en Guillermo del Toro analiza 'Roma', de Alfonso Cuarón, en 10 observaciones personales. Fotogramas. Versión electrónica disponible en https://www.fotogramas.es/noticias-cine/a25894307/guillermo-toro-analisis-roma-alfonsocuaron-netflix/ último acceso 13/12/2019.

Žižek, S. (2019). Slavoj Žižek: Roma is being celebrated for all the wrong reasons. U.K. The Spectator. versión electrónica disponible en https://blogs.spectator.co.uk/2019/01/roma-isbeing-celebrated-for-all-the-wrong-reasons-writes-slavoj-zizek/ último acceso 13/12/2019. 